\title{
Neutrophil Gelatinase-Associated Lipocalin and Hepcidin: What Do They Have in Common and Is There a Potential Interaction?
}

\author{
Jolanta Malyszko ${ }^{a} \quad$ Vladimir Tesar $^{b}$ lain C. Macdougallc \\ aDepartment of Nephrology and Transplantology, Medical University, Bialystok, Poland; \\ ${ }^{b}$ Department of Nephrology, 1st School of Medicine, Charles University, Prague, Czech Republic; \\ 'Department of Renal Medicine, King's College Hospital, London, UK
}

\section{Key Words}

Iron · Neutrophil gelatinase-associated lipocalin $\cdot$ Hepcidin

\begin{abstract}
Iron is the fourth most common element in the Earth's crust and is crucial for life. Over the last few years, our understanding of iron metabolism has dramatically increased due to the discovery of hepcidin, which is produced by hepatocytes and modulated in response to anemia, hypoxia and inflammation. It has been found that anemia upregulates lipocalin 2 (NGAL; neutrophil gelatinase-associated lipocalin) in the liver and serum. The aim of this review is to summarize the current knowledge dealing with a possible role of hepcidin and NGAL in iron metabolism and its regulation, particularly in kidney disease. Elevated NGAL a few days after insult is a possible preventive or protective mechanism limiting renal injury. NGAL is an innate antibacterial factor as well as hepcidin. NGAL binds siderophores, thereby preventing iron uptake by bacteria. Hepcidin, an antibacterial defensin, prevents iron absorption from the gut and iron release from macrophages, leading to hypoferremia and anemia. Both proteins sequester iron, but by different mechanisms. However, these proteins involved in iron metabolism do not
\end{abstract}

seem to be independently related. Taking into account the antimicrobial moieties of NGAL, further studies are needed to address the role of NGAL in iron metabolism and inflammation in renal failure.

Copyright $\odot 2010$ S. Karger AG, Basel

Iron is the fourth most common element in the Earth's crust and the most abundant transition metal in the human body. It is a paradoxical element in that it is required by all aerobic organisms, as it is essential for growth and survival. It is essential primarily to ensure transport of oxygen or to catalyze reactions of electron transfer, nitrogen fixation or DNA synthesis. On the other hand, it is also toxic due to its capacity to react with oxygen and to catalyze the production of reactive oxygen species. Iron is virtually insoluble under conditions occurring in our cells and body fluids, and maintaining the correct iron balance is crucial for health. All living organisms have evolved sophisticated mechanisms to maintain appropriate iron levels in their cells and within their body [1]. Over the last few years, our understanding of iron metabolism has dramatically increased due to the discovery of hepcidin. The regulation of iron metabolism involves the in-

Prof. Jolanta Malyszko, FASN

Department of Nephrology and Transplantology

Medical University, Zurawia 14

PL-15-540 Bialystok (Poland)

Tel. +48 857409 464, Fax +48 857434 586, E-Mail jolmal@ poczta.onet.pl 
Table 1. Proteins involved in iron metabolism

\begin{tabular}{|c|c|}
\hline Protein & Description, potential role \\
\hline Transferrin & $\begin{array}{l}\text { usually measured in the laboratory as the } \\
\text { total iron-binding capacity }\end{array}$ \\
\hline $\begin{array}{l}\text { Transferrin } \\
\text { receptor-sTFR }\end{array}$ & carrier protein for transferrin \\
\hline Ferritin & $\begin{array}{l}\text { the cellular storage protein for iron and an } \\
\text { acute phase reactant }\end{array}$ \\
\hline $\begin{array}{l}\text { Iron responsive } \\
\text { element-binding } \\
\text { protein }\end{array}$ & $\begin{array}{l}\text { an intracellular reporter of iron status, which } \\
\text { is also called iron regulatory protein or factor }\end{array}$ \\
\hline HFE & $\begin{array}{l}\text { hemochromatosis gene, which has been } \\
\text { detected, as well as mutations of which are } \\
\text { responsible for hereditary hemochromatosis }\end{array}$ \\
\hline $\begin{array}{l}\text { Divalent metal } \\
\text { transporter }\end{array}$ & $\begin{array}{l}\text { also known as DMT1, Nramp2, DCT1, } \\
\text { solute carrier family 11, member } 2 \text { (Slc11a2) }\end{array}$ \\
\hline $\begin{array}{l}\text { Duodenal iron } \\
\text { transporter-SFT }\end{array}$ & a stimulator of iron transport \\
\hline Ferroportin & iron export protein \\
\hline Hephaestin & iron export protein \\
\hline Hemojuvelin & a hepcidin regulator \\
\hline Hepcidin & $\begin{array}{l}\text { a negative regulator of intestinal iron absorp- } \\
\text { tion as well as macrophage iron release }\end{array}$ \\
\hline
\end{tabular}

teraction of a number of specific proteins as well as the interplay between iron absorption and iron loss [1]. Proteins involved in iron metabolism are presented in table 1 [1].

The normal iron content of the human body is about 3-4 g, predominantly in the form of hemoglobin in circulating erythrocytes (approximately $2.5 \mathrm{~g}$ ), iron-containing proteins such as myoglobin, cytochromes, catalase (about $400 \mathrm{mg}$ ), bound to transferrin (3-7 mg) [1]. The remainder is storage iron in the form of ferritin or hemosiderin.

The majority of iron is bound up in hemoglobin, though several proteins bind iron directly. Normally, one third of transferrin is saturated with iron (i.e. Fe/TIBC = 33\%) [1]. Transferrin transports iron between cells. Transferrin receptors are present on hepatocytes and epithelial cells of the small intestine, including duodenal crypts [1]. They probably contribute to the body's iron sensing [1]. Each receptor can bind two transferrin molecules and, after their endocytosis, iron is offloaded (four $\mathrm{Fe}^{3+}$ atoms) in acidified vacuoles. The complex of the apotransferrin and transferrin receptor is then recycled on the cell surface and released into circulation [1].

Ferritin is the cellular storage protein for iron. Ferritin is also an acute phase reactant and, along with transferrin and the transferrin receptor, is a member of the protein family that orchestrates the cellular defense against stress and inflammation [1]. The serum level of ferritin generally reflects overall iron storage, with $1 \mathrm{ng}$ of ferritin per $\mathrm{ml}$ approximating $10 \mathrm{mg}$ of iron stores [2].

Ferroportin has been found to be strongly expressed in enterocytes, macrophages and placental syncytiotrophoblasts $[3,4]$. It is a major iron transporter out of cells. It transports iron from the mother to the fetus, transfers absorbed iron from enterocytes into the circulation and participates in the recycling of iron from senescent erythrocytes into macrophages, and from them into the circulation. Ferroportin is upregulated by the amount of available iron [5], and downregulated through its interaction with hepcidin [6].

\section{Kidney and Iron Metabolism}

It has been shown recently that the kidney is also involved in iron metabolism. There is abundant expression of Nramp2 (DCT1) in the proximal tubule and collecting ducts of the kidney [7]. This raises the possibility that there is an iron excretory pathway in the kidney, counteracted by its constitutive reabsorption. On the other hand, Nramp1 expressed in the neutrophil granules known to harbor NGAL and lactoferrin is believed to reduce the availability of iron in the phagocytic vacuoles by pumping iron into the cytosol.

\section{Iron and Host Defence}

Iron also plays an important role in host defense responses to infectious agents. There are several host defense proteins, such as lactoferrin and siderocalin (lipocalin 2, NGAL), both or which are released from neutrophils at sites of infection/inflammation, or divalent metal transporter protein (DMT-1), which is a transmembrane protein and an isoform of natural resistance-associated macrophage protein (Nramp2), which seem to function in infected tissue or cells to sequester iron from invading microorganisms [1]. The growth and metabolism of many microorganisms is exquisitely iron-sensitive [8]. Bacteria require iron for the production of the 
Fig. 1. The main pathways of iron storage and exportation by macrophages, and the potential role of hepcidin and NGAL in restricting bacterial growth. Apo-NGAL = NGAL devoid of iron or siderophore. Modified from Muñoz et al. [55].

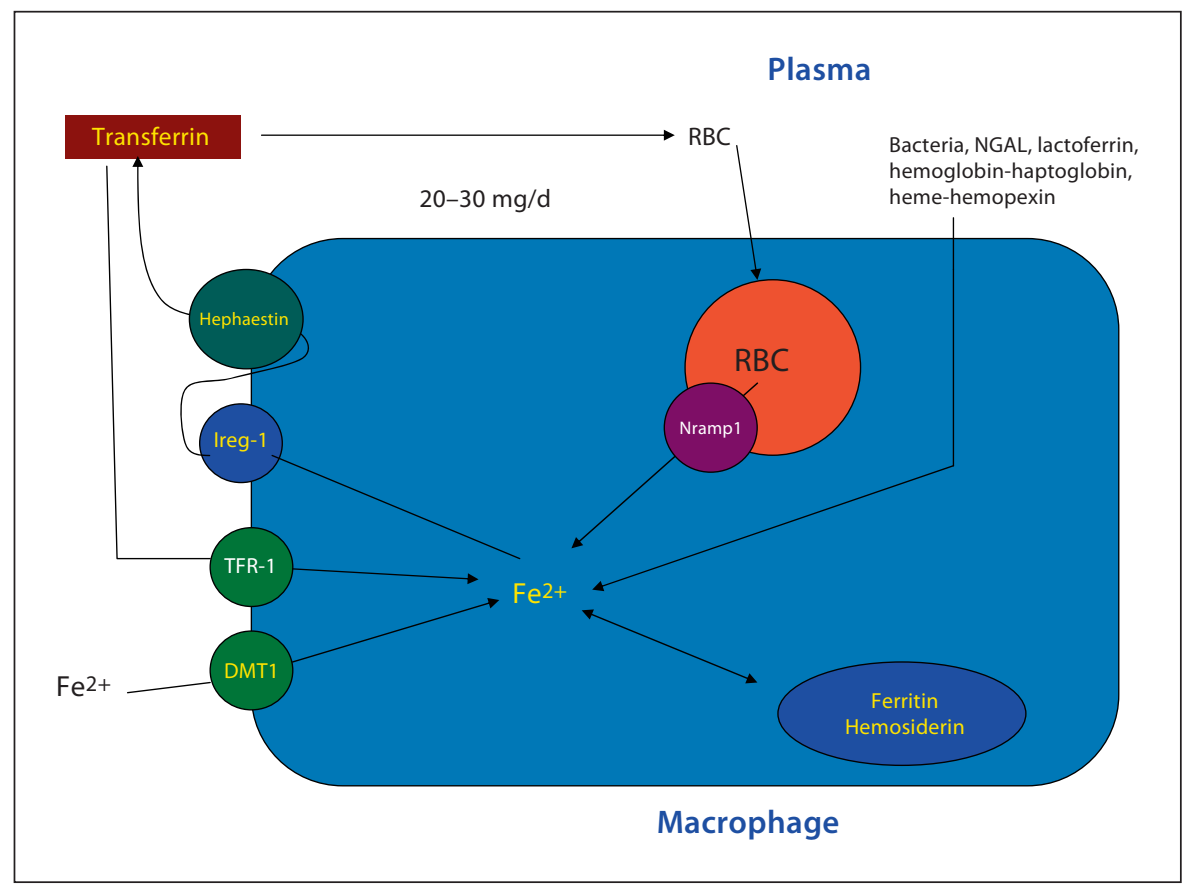

superoxide dismutase that protects them from host oxygen radicals [9]. Since the iron concentration in the environment or in the host is too low to sustain the optimal conditions for invading microorganisms, both bacteria and the host mechanisms have to tackle this problem. Bacteria-developed siderophores (high-affinity ironbinding molecules) retrieve iron from transferrin or lactoferrin of the host (fig. 1). Defense mechanisms of the host include an increased production of iron-binding proteins (i.e. transferrin), a fall in dietary iron absorption, an increase in iron storage proteins and release of apolactoferrin from neutrophils to sequester the iron at the site of invading microorganisms. Hypoferremia develops within hours of the inflammatory stimulus in order to counteract pathogens and retard tumor growth [10]. The finding that administration of iron during infection/inflammation worsens the course of the disease stresses the problem of the scarcity of free iron in the body and the efficiency of iron sequestration as an antibacterial strategy [11].

\section{NGAL and Iron and Anemia}

Lipocalins are a diverse family of over 20 small soluble proteins, which are often secreted. They have a three-dimensional structure, which comprises a single eightstranded, continuously hydrogen-bonded antiparallel $\beta$ barrel. It forms an enclosing cavity capable of binding several low molecular weight molecules, including iron $[12,13]$. Generally, lipocalins are considered as transporters with several different functions, including immune response, cell growth, proliferation and metabolism, iron transportation, and synthesis of prostaglandins [14].

NGAL is a protein of the lipocalin family group of molecules that bind low molecular weight ligands and function in various biological processes ranging from vitamin delivery to pheromone transport [12-15]. NGAL is a $25-\mathrm{kDa}$ monomer with neutrophil gelatinase, although the association appears to be functionally irrelevant [15]. NGAL is thought to be an acute-phase protein with upregulated expression in different inflammatory conditions as well as in different cancers [15]. Recently, it has been found that NGAL binds small iron-carrying molecules (so called siderophores) and it is critical in various states, including bacterial infection and kidney injury [16-18]. Its potency as a bacteriostatic agent is due to the sequestration of iron, thus depriving bacteria of iron, leading to failure to grow and subsequent death [16]. NGAL was also reported to protect MMP-9 (matrix metalloproteinase 9) from degradation. Moreover, NGAL was demonstrated to protect against acute ischemic kidney injury [19] and urinary NGAL was found to aid in the noninvasive diagnosis of HIV-associated nephropathy and screen for HIV-associated nephropathy-related tubular damage [20]. 
In his elegant paper, Goetz et al. [16] revealed the mechanism of NGAL antibacterial iron depletion strategy of the innate immune system. At the site of inflammation/infection, NGAL is released by neutrophils to sequester bacterial ferric siderophores. NGAL only binds iron in complex with a nonheme compound. More precisely, it tightly binds bacterial catecholate-type ferric siderophores through a cyclically permuted hybrid electrostatic/cation- $\pi$ interaction, while at the same time other components of the innate immune system, such as lactoferrin, simply bind to and sequester free iron. Further support for this finding came from the study on NGALdeficient mice conducted by Flo et al. [21], which developed a markedly increased sensitivity to Gram-negative bacterial infections and an increased susceptibility to death from sepsis [22].

It has been suggested that NGAL comprises a critical component of innate immunity to exogenous bacterial infections. This is consistent with normal expression of NGAL in a number of human tissues typically exposed to the external environment, including the respiratory, gastrointestinal and urinary tracts [23]. Moreover, as suggested by Schmidt-Ott et al. [24], distal nephron-urinary NGAL, synthesized in acute kidney injury and chronic kidney disease, acts as a prophylactic antimicrobial agent preventing ascending infection from the lower urinary tract.

Recently, the potential role of NGAL as a biomarker of acute kidney injury was highlighted [25]. Mislocalized iron may be the underlying mechanism of the acute tubular necrosis [26]. Iron-catalyzed damage is thought to be one of the earliest events in kidney dysfunction. In post-ischemic kidney, NGAL is markedly upregulated in proximal tubules and the distal nephron segment [19]. In the former, it co-localizes at least in part with proliferating epithelial cells [19]. The similar pattern of proximal tubule NGAL expression was observed following nephrotoxic injury after cisplatin administration [26]. In the mouse model of ischemia-reperfusion kidney injury, administration of recombinant NGAL before or just after the insult resulted in marked preservation of kidney structure and function. It also attenuates apoptosis of tubule cells and enhances tubular cell proliferation [19].

NGAL could potentially recycle iron into the viable cells, thus stimulating growth and development. NGAL may also serve as a storage place for iron released from damaged tubule cells. By removing iron from the site of injury, NGAL may limit iron-mediated cytotoxicity. These protective effects were due to simultaneous transport of iron and siderophores to the proximal tubules. At the same time, upregulation of heme-oxygenase-1 (a protective antioxidant) and preservation of $\mathrm{N}$-cadherin expression in the proximal tubules were demonstrated [19]. NGAL was also identified as iron-transporting protein during nephrogenesis [18]. However, the overall repertoire of NGAL function remains to be established.

Some suggestions on a possible relationship between NGAL and anemia were proposed by Jiang et al. [27]. They found that anemia upregulated lipocalin 2 in the liver and serum in a murine model. In addition, WeizerStern et al. [28] studying thalassemia, an inherited anemia, reported decreased hepcidin expression together with increased NGAL expression in the liver in a thalassemia intermedia mouse model. Ho et al. [29] studied urine biomarkers of acute kidney injury (using mass spectrometry-proteomic analysis). They reported the opposite predictive effects for the development of acute kidney injury of urinary hepcidin and NGAL. Upregulation of hepcidin in the thick ascending limb of the cortex and connecting tubules after renal ischemia may lead to downregulation of the ferroportin exporter, preventing the further release of free toxic iron $[29,30]$. Moreover, expression of hepcidin in the liver is regulated, not only by hypoxia, anemia and inflammation, but also by hemojuvelin (as a co-receptor) and the bone morphogenetic protein pathway. NGAL, by binding to siderophore iron, limits iron availability to possible pathogens. Thereafter, the NGAL-siderophore complex delivers iron into cells to permit growth and development [16]. While information today has implicated NGAL-mediated iron uptake only in renal development, it is possible that it functions elsewhere, particularly when normal pathways are absent.

\section{Hepcidin and Iron}

On the other hand, our understanding of the molecular control of iron metabolism has increased dramatically over the past 5 years due to the discovery of hepcidin $[31,32]$. This is a circulating antimicrobial peptide mainly synthesized in the liver, which has recently been proposed as a factor regulating the uptake of dietary iron and its mobilization from macrophages and hepatic stores. Kulaksiz et al. [7] suggested that the kidneys, in addition to the liver, are involved not only in the synthesis, but may also participate in hepcidin elimination as well. Hepcidin seems to be filtered and reabsorbed in the proximal tubule, similarly to $\beta 2$-microglobulin [33].

Hepcidin connections to iron metabolism were postulated by Nicolas et al. [34] and Pigeon et al. [35]. Nicolas et al. [34] identified that the murine gene hepcidin had a 
role in iron metabolism completely serendipitously as they were working on glucose metabolism-related transcription factor USF2 (upstream stimulatory factor 2) knockout mice, which unexpectedly were iron-overloaded. Pigeon et al. [35] was searching for iron upregulated genes when they discovered that murine hepcidin mRNA expression was increased by iron overload and decreased by iron depletion. Injection of hepcidin inhibited intestinal iron absorption in mice independent of their iron status and did not require the HFE gene product [36]. Rivera et al. [3] showed that hepcidin injection results in dose-dependent hypoferremia. On the other hand, iron administration in humans induced hepcidin secretion in urine [37].

These findings suggest that hepcidin plays a role as a negative regulator of intestinal iron absorption and iron release from macrophages. Evidence from transgenic mouse models indicates that hepcidin is the predominant negative regulator of iron absorption in the small intestine, iron transport across the placenta and iron release from macrophages [38]. Hepcidin controls intestinal iron absorption by regulating ferroportin expression on the basolateral membrane of enterocytes [39]. Hepcidin directly regulates the expression of ferroportin on cell membranes, binding to ferroportin and inducing its internalization and degradation, thus trapping iron in enterocytes, macrophages and hepatocytes. The net effect of hepcidin is the diminished absorption of dietary iron, sequestration of iron in macrophages and sequestration of iron in hepatic stores.

Hepcidin is an acute phase protein [40] that is synthesized to restrict the body's iron stores and prevent iron from being requisitioned by invading microorganisms, but this does not explain how it responds to the body's iron needs. It is possible that this missing link involves hypoxia.

Recently, matriptase-2, a liver transmembrane serine protease, has been found to have a major role in controlling hepcidin gene expression. In mice, defects in the Tmprss6 gene encoding matriptase- 2 result in high hepcidin expression and cause severe microcytic anemia. Similarly, mutations in the human TMPRSS6 gene have been identified in patients with iron-refractory iron deficiency anemia-IRIDA [41]. IRIDA is associated with severe microcytosis, whereas the anemia of chronic disease is typically normocytic. In IRIDA high serum ferritin, low TSAT, even after parenteral iron treatment, is typical for findings.

NGAL and Hepcidin

\section{Hepcidin and Iron and NGAL}

Patients with chronic kidney disease have a chronic inflammatory state. This is due to many underlying factors, including an enhanced incidence of infections, the uremic milieu, elevated levels of proinflammatory cytokines, frequent presence of widespread arteriosclerosis, etc. There are additional factors with hemodialysis which may contribute to this process (impure dialysate, bio-incompatible dialysis membranes, intercurrent infections) [42-45]. In addition, iron metabolism is disturbed in chronic inflammatory diseases. Iron supplementation is often introduced in dialyzed patients to replete or to maintain iron stores, particularly in patients treated with erythropoiesis-stimulating agents.

Recently, Bolignano et al. [46] have suggested that altered NGAL levels in hemodialyzed patients were probably due to the fact that this protein was involved in iron metabolism. They suggested that elevated NGAL was probably related to its involvement in iron equilibrium. They reported that NGAL was predicted by hsCRP, TSAT and spKt/V. They also proposed that NGAL might be a new tool in the assessment of iron deficiency. In our recent study, we tested the hypothesis that NGAL might be related to hepcidin, not only to iron metabolism prevalent in hemodialyzed patients [47]. We found that in multiple regression analysis, residual renal function, hepcidin, creatinine and hsCRP were predictors of serum NGAL in hemodialyzed patients. We concluded that NGAL was highly induced in dialyzed patients. NGAL could reflect both kidney function and iron metabolism. However, these proteins involved in iron metabolism do not seem to be independently related.

It has been shown recently that the kidney is also involved in iron metabolism, as hepcidin was isolated from human urine [31]. On the other hand, NGAL, which was discovered by serendipity, is an iron-trafficking protein, a member of the non-transferrin-bound iron pool and an alternative to the transferrin-mediated iron-delivery pathway [17]. Both NGAL and hepcidin express antimicrobial properties. NGAL binds siderophores and interrupts the enterochelin-specific iron acquisition by bacteria, whereas hepcidin, an acute phase reactant, has intrinsic antibacterial activity like defensins killing on contact $[48,49]$ (fig. 2). Bacteria-developed siderophores retrieve iron from transferrin or lactoferrin of the host. However, while lactoferrin chelates iron directly, NGAL is unique in that it is specific for iron reserved for bacterial use as a ferric siderophore complex. The host has also developed defense mechanisms, such as increased production of iron-binding proteins (i.e. transferrin), fall in

Kidney Blood Press Res 2010;33:157-165 


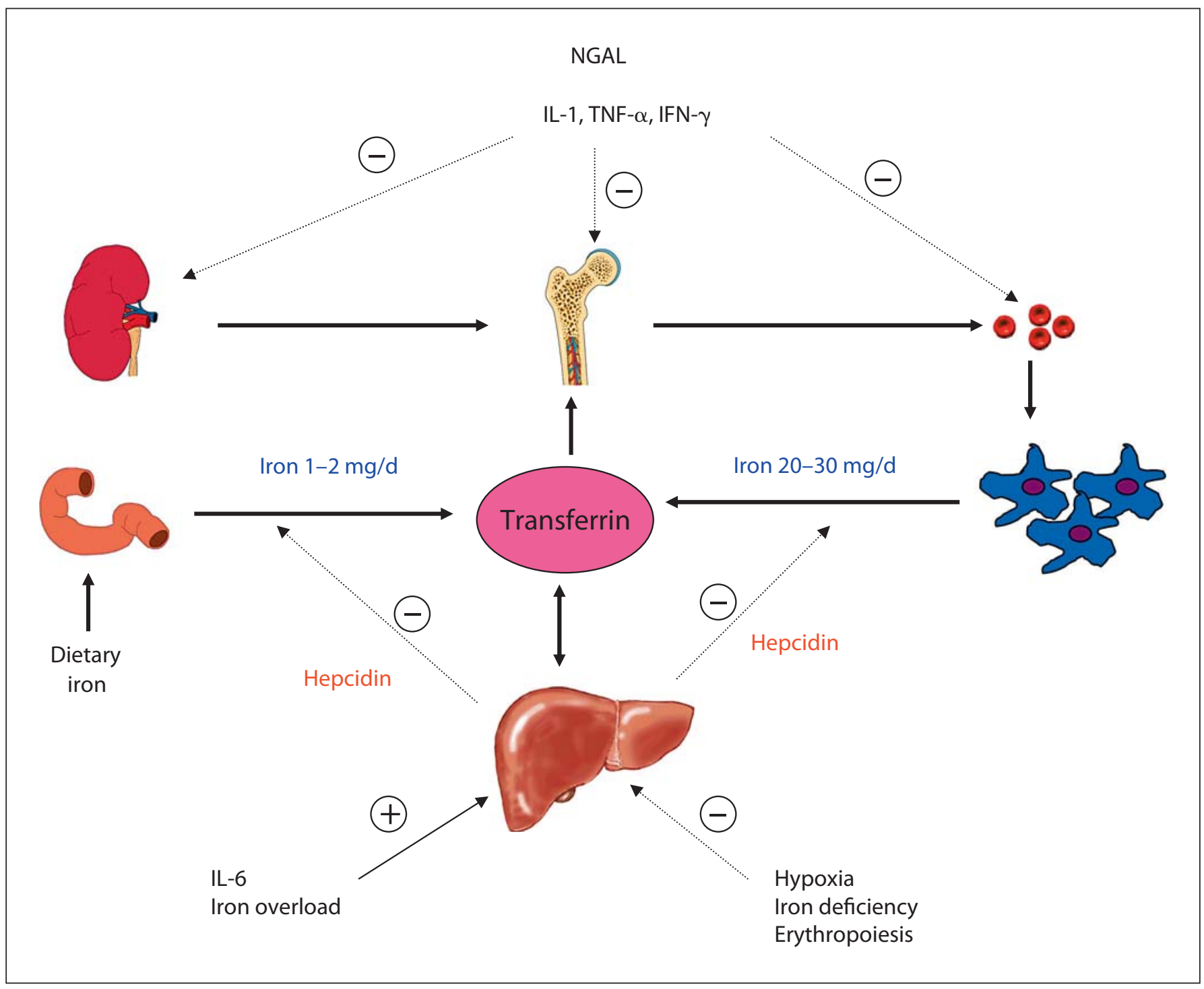

Fig. 2. Effects of inflammation on erythropoiesis and iron homeostasis. The mechanism of action of hepcidin and NGAL (via IL-1 pathway).

dietary iron absorption, increase in iron storage proteins, and release of apolactoferrin from neutrophils to sequester the iron at the site of the invading microorganism. Hepcidin, by inducing sequestration of iron in macrophages, robs bacteria of this element. Defensins are antimicrobial peptides produced by cells of epithelial lining [50]. Hepcidin wards off infections, in part as a defensin (it possesses antimicrobial activity) and an acute phase protein [40], as well as by causing hypoferremia [51]. Moreover, hepcidin could be a key defense mechanism in the 'evolutionary oversight' according to Ashrafian
[52] due to its role in iron metabolism. In addition, both proteins are associated with inflammation as well. Similarly, NGAL-binding bacterial catecholate-type ferric siderophores act as potent bacteriostatic agents by sequestrating iron.

Elevated NGAL a few days after insult is a possible preventive or protective mechanism for limiting renal injury; however, extracorporeal circulation, such as a hemodialysis session, is a permanent insult to the body. We have to bear in mind that NGAL is an innate antibacterial factor as well as hepcidin. Microorganisms have de- 


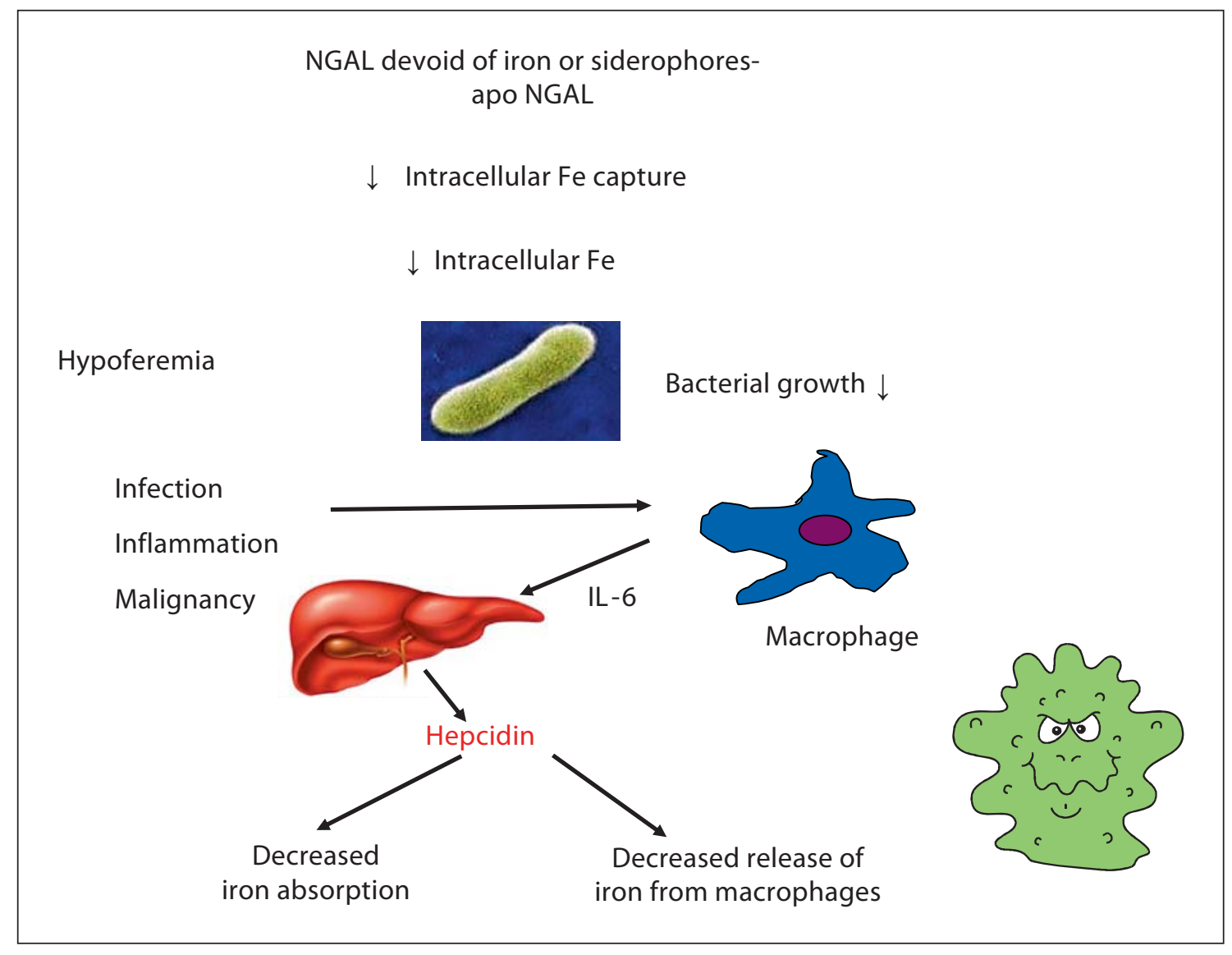

Fig. 3. Iron metabolism in the macrophage.

veloped several mechanisms to secure their iron supply (which is very scarce as a soluble molecule). The major mechanism is the ability to synthesize siderophores, the strongest known iron chelators. They are able to recover iron from transferrin and lactoferrin. NGAL binds siderophores, thereby preventing iron uptake by bacteria. Hepcidin, an antibacterial defensin highly induced in the liver as a response to IL-6 stimulation, prevents iron absorption from the gut and iron release from macrophages, leading to hypoferremia and anemia. Both proteins, therefore, sequester iron, but by different mechanisms (fig. 3).

At the present time, there is a lack of validated assays and robust data available for both hepcidin and NGAL; therefore, their possible relationship is still a matter of debate. Further research will hopefully elucidate this potential interaction. At present, there is no consensus on the best assay for hepcidin measurement, and assays for hepcidin detection and quantification in serum or urine have not been generally available. Recently, other serum hepcidin assays based on the surface-enhanced laser desorption/ionization time of flight mass spectrometry (SELDI-TOF MS), liquid chromatography tandem mass spectrometry (LC-MS/MS) and isotope dilution microHPLC-tandem mass spectrometry were developed, but they are not widely and commercially available [53]. ELISA and RIA assays for hepcidin determination are commercially available. There is also a commercially available ELISA assay for NGAL determination on both serum/plasma and urine. Moreover, using a point-of-care device (Triage, Inverness, Fla., USA), whole blood or plasma NGAL levels could be easily quantitatively available in $15 \mathrm{~min}$ and the device requires only a microliter sample. Urinary NGAL assay requires only $150 \mu$ l of urine, and results are available within $35 \mathrm{~min}$ on the Architect (Abbott) platform.

In conclusion, the subclinical inflammatory state is frequently found in chronic kidney disease. Moreover, 
chronic kidney disease is associated with an impaired immune system. Both NGAL and hepcidin, elevated in chronic kidney disease, are not only involved in iron metabolism, but are also associated with inflammation and may be related to anemia. However, there is still an open question as to whether anemia in chronic kidney disease is the price to pay or an adaptive mechanism? As reported recently, anti-hepcidin antibody treatment modulated iron metabolism and was effective in a mouse model of inflammation-induced anemia [54]. Whether this treatment would be effective in humans remains to be established, as does a possible role of NGAL in the modulation of iron metabolism and its contribution to anemia.

\section{References}

1 Beaumont C, Beris P, Beuzard Y, Brugnara C: Disorders of Erythropoiesis, Erythrocytes and Iron Metabolism. Forum Service Editore, Genoa, 2009.

-2 Nemeth E, Tuttle MS, Powelson J, Vaughn MB, Donovan A, Ward DM, Ganz T, Kaplan $\mathrm{J}$ : Hepcidin regulates cellular iron efflux by binding to ferroportin and inducing its internalization. Science 2004;306:2090-2093.

$\checkmark 3$ Rivera S, Nemeth E, Gabayan V, Lopez MA, Farshidi D, Ganz T: Synthetic hepcidin causes rapid dose-dependent hypoferremia and is concentrated in ferroportin-containing organs. Blood 2005;106:2196-2199.

4 Delaby C, Pilard N, Goncalves AS, Beaumont C, Canonne-Hergaux F: The presence of the iron exporter ferroportin at the plasma membrane of macrophages is enhanced by iron loading and downregulated by hepcidin. Blood 2005;106:3979-3984.

5 Frazer DM, Anderson GJ: The orchestration of body iron intake: how and where do enterocytes receive their cues? Blood Cells Moll Dis 2003;30:288-297.

-6 Andrews NC: Molecular control of iron metabolism. Best Pract Res Clin Haematol 2005; 18:159-169.

7 Kulaksiz H, Gehrke SG, Janetzko A, Rost D, Bruckner T, Kallinowski B, Stremmel W: Pro-hepcidin: expression and cell specific localisation in the liver and its regulation in hereditary haemochromatosis, chronic renal insufficiency, and renal anaemia. Gut 2004; 53:735-743.

8 Dey R, Datta SC: Leishmanial glycosomes contain superoxide dismutase. Biochem J 1994;301:317-319.

\9 Zhang Y, Lathigra R, Garbe T, Catty D, Young D: Genetic analysis of superoxide dismutase, the 23 kilodalton antigen of mycobacterium tuberculosis. Mol Microbiol 1991; 5:381-391.

10 Weinberg ED: Iron withholding: a defense against infection and neoplasia. Physiol Rev 1984;64:65-102.

11 Weinberg ED: Iron availability and infection. Biochim Biophys Acta 2009;1790:600605.
12 Cowland JB, Borregaard N: Molecular characterization and pattern of tissue expression of the gene for neutrophil gelatinase-associated lipocalin from humans. Genomics 1997; 45:17-23.

13 Risso A: Leukocyte antimicrobial peptides: multifunctional effector molecules of innate immunity. J Leukoc Biol 2000;68:785-792.

14 Borregaard N, Cowland JB: Neutrophil gelatinase-associated lipocalin, a siderophorebinding eukaryotic protein. Biometals 2006; 19:211-215.

15 Tong Z, Wu X, Ovcharenko D, Zhu J, Chen CS, Kehrer JP: Neutrophil gelatinase-associated lipocalin as a survival factor. Biochem J 2005;391:441-448.

16 Goetz DH, Holmes MA, Borregaard N, Bluhm ME, Raymond KN, Strong RK: The neutrophil lipocalin NGAL is a bacteriostatic agent that interferes with siderophore-mediated iron acquisition. Mol Cell 2002;10: 1033-1043.

17 Yang J, Goetz D, Li JY, Wang W, Mori K, Setlik D, Du T, Erdjument-Bromage H, Tempst P, Strong R, Barasch J: An iron delivery pathway mediated by a lipocalin. Mol Cell 2002; 10:1045-1056.

18 Yang J, Mori K, Li JY, Barasch J: Iron, lipocalin, and kidney epithelia. Am J Physiol Renal Physiol 2003;285:F9-F18.

$\checkmark 19$ Mori K, Lee HT, Rapoport D, Drexler IR, Foster K, Yang J, Schmidt-Ott KM, Chen X, Li JY, Weiss S, Mishra J, Cheema FH, Markowitz G, Suganami T, Sawai K, Mukoyama M, Kunis C, D’Agati V, Devarajan P, Barasch J: Endocytic delivery of lipocalin-siderophore-iron complex rescues the kidney from ischemia-reperfusion injury. J Clin Invest 2005;115:610-621.

-20 Paragas N, Nickolas TL, Wyatt C, Forster CS, Sise M, Morgello S, Jagla B, Buchen C, Stella P, Sanna-Cherchi S, Carnevali ML, Mattei S, Bovino A, Argentiero L, Magnano A, Devarajan P, Schmidt-Ott KM, Allegri L, Klotman P, D'Agati V, Gharavi AG, Barasch J: Urinary NGAL marks cystic disease in HIVassociated nephropathy. J Am Soc Nephrol 2009;20:1687-1692.
21 Flo TH, Smith KD, Sato S, Rodriguez DJ, Holmes MA, Strong RK, Akira S, Aderem A: Lipocalin 2 mediates an innate immune response to bacterial infection by sequestrating iron. Nature 2004;432:917-921.

22 Berger T, Togawa A, Duncan GS, Elia AJ, You-Ten A, Wakeham A, Fong HE, Cheung CC, Mak TW: Lipocalin 2-deficient mice exhibit increased sensitivity to Escherichia coli infection but not to ischemia-reperfusion injury. Proc Natl Acad Sci USA 2006; 103:18341839.

$23 \mathrm{Xu} \mathrm{S}$, Venge P: Lipocalins as biochemical markers of disease. Biochim Biophys Acta 2000;1482:298-307.

-24 Schmidt-Ott KM, Mori K, Kalandadze A, Li JY, Paragas N, Nicholas T, Devarajan P, Barasch J: Neutrophil gelatinase-associated lipocalin-mediated iron traffic in kidney epithelia. Curr Opin Nephrol Hypertens 2006; 15:442-449.

-25 Mishra J, Ma Q, Prada A, Mitsnefes M, Zahedi K, Yang J, Barasch J, Devarajan P: Identification of neutrophil gelatinase-associated lipocalin as a novel early urinary biomarker for ischemic renal injury. J Am Soc Nephrol 2003; 14:2534-2543.

26 Mishra J, Mori K, Ma Q, Kelly C, Barasch J, Devarajan P: Neutrophil gelatinase-associated lipocalin: a novel early urinary biomarker for cisplatin nephrotoxicity. Am J Nephrol 2004;24:307-315.

27 Jiang W, Constante M, Santos MM: Anemia upregulates lipocalin 2 in the liver and serum. Blood Cells Mol Dis 2008;41:169-174.

28 Weizer-Stern O, Adamsky K, Amariglio N, Rachmilewitz E, Breda L, Rivella S, Rechavi G: mRNA expression of iron regulatory genes in beta-thalassemia intermedia and beta-thalassemia major mouse models. Am J Hematol 2006;81:479-483.

29 Ho J, Lucy M, Krokhin O, Hayglass K, Pascoe E, Darroch G, Rush D, Nickerson P, Rigatto C, Reslerova M: Mass spectrometry-based proteomic analysis of urine in acute kidney injury following cardiopulmonary bypass: a nested case-control study. Am J Kidney Dis 2009;53:584-595. 
- 30 Hingorani S, Molitoris BA, Himmelfarb J: Ironing out the pathogenesis of acute kidney injury. Am J Kidney Dis 2009;53:569-571.

- 31 Park CH, Valore EV, Waring AJ, Ganz T: Hepcidin, a urinary antimicrobial peptide synthesized in the liver. J Biol Chem 2001; 276:7806-7810

- 32 Krause A, Neitz S, Magert HJ Schyltz A, Forssmann WG, Schulz-Knappe P, Adermann L: LEAP-1, a novel highly disulfidebonded human peptide exhibits antimicrobial activity. FEBS Lett 2000;480:147-150.

- 33 Swinkels DW, Girelli D, Laarakkers C, Kroot J, Campostrini N, Kemna EH, Tjalsma H: Advances in quantitative hepcidin measurements by time-of-flight mass spectrometry. PLoS One 2008;3:e2706.

- 34 Nicolas G, Bennoun M, Devaux I, Beaumont C, Grandchamp B, Kahn A, Vaulont S: Lack of hepcidin gene expression and severe tissue iron overload in upstream stimulatory factor 2 (USF2) knockout mice. Proc Natl Acad Sci USA 2001;98:8780-8785.

- 35 Pigeon C, Ilyin G, Courselaud B, Leroyer P, Turlin B, Brissot P, Loreal O: A new mouse liver-specific gene, encoding a protein homologous to human antimicrobial peptide hepcidin, is overexpressed during iron overload. J Biol Chem 2001;276:7811-7819.

-36 Laftah AH, Ramesh B, Simpson RJ, Solanky N, Bahram S, Schumann K, Debnam ES, Srai SK: Effect of hepcidin on intestinal iron absorption in mice. Blood 2004;103:39403944.

- 37 Nemeth E, Rivera S, Gabayan V, Keller C, Taudorf S, Pedersen BK, Ganz T: IL-6 mediates hypoferremia of inflammation by inducing the synthesis of the iron regulatory hormone hepcidin. J Clin Invest 2004;113: 1271-1276.

-38 Ganz T: Hepcidin, a key regulator of iron metabolism and mediator of anemia of inflammation. Blood 2003;102:783-788.
39 Ganz T: Hepcidin - a regulator of intestinal iron absorption and iron recycling by macrophages. Best Pract Res Clin Haematol 2005; 18:171-182.

40 Nemeth E, Valore EV, Territo M, Schiller G, Lichtenstein A, Ganz T: Hepcidin, a putative mediator of anemia of inflammation, is a type II acute-phase protein. Blood 2003;101: 2461-2463.

41 Cui Y, Wu Q, Zhou Y: Iron-refractory iron deficiency anemia: new molecular mechanisms. Kidney Int 2009;76:1137-1141.

42 Panichi V, Migliori M, De Pietro S, Taccola D, Bianchi AM, Norpoth M, Metelli MR, Giovannini L, Tetta C, Palla R: C reactive protein in patients with chronic renal diseases. Ren Fail 2001;23:551-562.

43 Stenvinkel $\mathrm{P}$, Heimburger O, Wang T, Lindholm B, Bergstrom J, Elinder CG: High serum hyaluronan indicates poor survival in renal replacement therapy. Am J Kidney Dis 1999;34:1083-1088.

-44 Chung SH, Heimburger O, Stenvinkel P, Bergstrom J, Lindholm B: Association between inflammation and changes in residual renal function and peritoneal transport rate during the first year of dialysis. Nephrol Dial Transplant 2001;16:2240-2245.

45 Pecoits-Filho R, Heimburger O, Barany $\mathrm{P}$ Suliman M: Associations between circulating inflammatory markers and residual renal function in CRF patients. Am J Kidney Dis 2003;41:1212-1218.

46 Bolignano D, Coppolino G, Romeo A, De Paola L, Buemi A, Lacquaniti A, Nicocia G, Lombardi L, Buemi M: Neutrophil gelatinase-associated lipocalin (NGAL) reflects iron status in haemodialysis patients. Nephrol Dial Transplant 2009;24:33983403.
47 Malyszko J, Malyszko JS, Kozminski P, KocZorawska E, Mysliwiec M, Macdougall I: Possible relationship between NGAL (neutrophil gelatinase-associated lipocalin), hepcidin, and inflammation in hemodialyzed patients. Nephron 2010, in press.

-48 Yang D, Biragyn A, Hoover DM, Lubkowski J, Oppenheim JJ: Multiple roles of antimicrobial defensins, cathelicidins, and eosinophilderived neurotoxin in host defense. Annu Rev Immunol 2004;22:181-215.

-49 Hunter HN, Fulton DB, Ganz T, Vogel HJ: The solution structure of human hepcidin, a peptide-hormone with antimicrobial activity that is involved in iron uptake and hereditary hemochromatosis. J Biol Chem 2002; 277:37597-37603

-50 Risso A: Leukocyte antimicrobial peptides: multifunctional effector molecules of innate immunity. J Leukoc Biol 2000;68:785-792.

-51 Yang D, Biragyn A, Hoover DM, Lubkowski J, Oppenheim JJ: Multiple roles of antimicrobial defensins, cathelicidins, and eosinophilderived neurotoxin in host defense. Annu Rev Immunol 2004;22:181-215.

52 Ashrafian H: Hepcidin: the missing link between hemochromatosis and infections. Infect Immun 2003;71:6693-6700.

53 Malyszko J: Hepcidin assays: ironing out some details. Clin J Am Soc Nephrol 2009;4: 1015-1016.

54 Sasu BJ, Cooke KS, Arvedson TL, Plewa C, Ellison AR, Sheng J, Winters A, Juan T, Li H, Begley CG, Molineux G: Anti-hepcidin antibody treatment modulates iron metabolism and is effective in a mouse model of inflammation-induced anemia. Blood 2010;115: 3616-3624

55 Muñoz M, Villar I, Garcia-Erce JA: An update on iron physiology. World J Gastroenterol 2009;15:4617-4626. 